\title{
Brief Report \\ Analysis and Sequence Alignment of Peste des Petits Ruminants Virus ChinaSX2020
}

\author{
Lingxia Li, Jinyan Wu, Xiaoan Cao, Jijun He, Xiangtao Liu and Youjun Shang *
}

\author{
State Key Laboratory of Veterinary Etiological Biology, Lanzhou Veterinary Research Institute, Chinese Academy \\ of Agricultural Sciences, Lanzhou 730046, China; lilingxia963@foxmail.com (L.L.); wujinyan@caas.cn (J.W.); \\ caoxiaoan@caas.cn (X.C.); hejijun@caas.cn (J.H.); liuxiangtao@caas.cn (X.L.) \\ * Correspondence: shangyoujun@caas.cn
}

Citation: Li, L.; Wu, J.; Cao, X.; He, J.; Liu, X.; Shang, Y. Analysis and Sequence Alignment of Peste des Petits Ruminants Virus ChinaSX2020. Vet. Sci. 2021, 8, 285. https://doi.org/ $10.3390 /$ vetsci 8110285

Academic Editor: Patrick Butaye

Received: 14 October 2021

Accepted: 17 November 2021

Published: 22 November 2021

Publisher's Note: MDPI stays neutral with regard to jurisdictional claims in published maps and institutional affiliations.

Copyright: (c) 2021 by the authors. Licensee MDPI, Basel, Switzerland. This article is an open access article distributed under the terms and conditions of the Creative Commons Attribution (CC BY) license (https:// creativecommons.org/licenses/by/ $4.0 /)$.

\begin{abstract}
The peste des petits ruminants virus (PPRV) mainly infects goats and sheep and causes a highly contagious disease, PPR. Recently, a PPRV strain named ChinaSX2020 was isolated and confirmed following an indirect immunofluorescence assay and PCR using PPRV-specific antibody and primers, respectively. A sequencing of the ChinaSX2020 strain showed a genome length of 15,954 nucleotides. A phylogenetic tree analysis showed that the ChinaSX2020 genome was classified into lineage IV of the PRRV genotypes. The genome of the ChinaSX2020 strain was found to be closely related to PPRVs isolated in China between 2013 and 2014. These findings revealed that not a variety of PRRVs but similar PPRVs were continuously spreading and causing sporadic outbreaks in China.
\end{abstract}

Keywords: PPRV; genome; ChinaSX2020; sequence alignment

\section{Introduction}

Peste des petits ruminants (PPR), caused by the PPR virus (PPRV), is an acute and fatal contagious disease affecting the majority of small ruminants. It mainly affects the sheep industry worldwide, and the range of hosts infected with PPRV continues to increase [1,2]. PPRV is a member of the genus Morbillivirus in the family Paramyxoviridae. It is a negativestrand RNA virus, and the viral RNA of PPRV is $15.9 \mathrm{~kb}$ in length. According to the $\mathrm{N}$ and F genes of PPRV, the phylogenetic tree is divided into four lineages (I-IV) [3]. However, lineage IV is the most commonly found epidemic strain in China and other Asian regions.

In the last 20 years, PPRV has posed a great threat to the sheep and goat industry, as well as to public health. The spread of PPRV continues to increase among unvaccinated domestic small ruminants. The research has shown, through serological investigations in African countries and where PPRV is endemic, that PPRV repeatedly infects various wild animals [4]. Globally, PPR epidemics still have regional epidemic and multiregional distributions. Since PPR was first reported, this disease has continued to spread in more than 70 countries throughout the world [5]. In our previous study, we found that PPRV was circulating among wild goats in the Qilian, Helan and Yinshan mountains of China [6]. In addition, the geographic range of PPRV infection continues to expand, reaching previously uninfected areas. Now, the number of infected counties continues to increase, extending into Central and East Asia and Europe [7].

This virus spreads from livestock in multiple locations and at different times. The host range of PPRV infection is gradually expanding, with research showing that PPRV has the potential to adapt to a variety of new hosts $[8,9]$. According to the reported data from January 2014 to June 2018, PPR occurred every year in Hunan province of China. The latest outbreak of PPR was reported in Hunan province on 15 June 2018, with no new outbreaks ever since. In addition, Anhui, Jiangsu and Yunnan provinces had 30, 33 and 56 epidemic locations, respectively $[10,11]$. These studies suggested that the cross-border transmissions by wild and domestic animals were closely related to the spread of PPRV [12]. 
Every year, PPR infections cause huge economic losses worldwide. At present, there is no effective treatment or specific medicine for PPR, and prevention or control is mainly carried out through vaccine immunization. Therefore, a novel vaccine is a promising tool to help control this disease [13]. However, regional epidemics are still frequent due to immunization failures or other human factors. Thus, the continuous surveillance and monitoring of the circulating strains of PPRV would make a major contribution to the global campaign to eliminate this virus [14-16]. The objective of this study is to evaluate one whole-genome sequence of PPRV collected from Shannxi province of China, in order to provide primary data for epidemiological analysis of PPRV in China, even around the world.

\section{Materials and Methods}

\subsection{Cells and Virus}

Vero cells were cultured with MEM medium containing 10\% FBS and $100 \mu \mathrm{g} / \mathrm{mL}$ of streptomycin and $100 \mathrm{IU} / \mathrm{mL}$ of penicillin. Goat tracheal epithelium cells (GTC) were generously provided by Prof. Chu Yuefeng (Lanzhou Veterinary Research Institute) and were cultured in RPMI 1640 Medium (Gibco, Grand Island, NY, USA) containing 10\% FBS (Hyclone, Logan, UT, USA), $100 \mu \mathrm{g} / \mathrm{mL}$ of streptomycin and $100 \mathrm{IU} / \mathrm{mL}$ of penicillin. Then, the cells grew after five times for passages and were then stored in our laboratory. For virus infection, the experiments were performed similarly as in [6].

\subsection{Indirect Immunofluorescence Assay}

GTC were infected with PPRV ChinaSX2020 at the indicated multiplicity of infection (MOI) of 2.0 at $37^{\circ} \mathrm{C}$ for $2 \mathrm{~h}$. The PPRV inoculum was removed, and fresh 1640 medium containing $2 \%$ FBS was added back onto cells. RPMI-1640-treated cells were set as mock. PPRV infection with GTC at $24 \mathrm{~h}, 48 \mathrm{~h}$, and $72 \mathrm{~h}$ were collected. Then, the cells were fixed with $4 \%$ paraformaldehyde at RT for $30 \mathrm{~min}$. Cells were blocked with PBS containing $0.05 \%$ Tween 20 and $2 \%$ skim milk powder for $1 \mathrm{~h}$ at $37^{\circ} \mathrm{C}$. PPRV-N polyclonal antibody (1:200) was added and incubated at $4{ }^{\circ} \mathrm{C}$ overnight. The cells were washed three times with PBS and then incubated with FITC-conjugated secondary antibody (1:200) for $1 \mathrm{~h}$ at $37^{\circ} \mathrm{C}$. After washing five times with PBS in a dark place, then cells were detected under a fluorescence microscope.

\subsection{RNA Extraction, Quantitative Real-Time PCR and Genome Sequencing}

Clinical samples including spleen, small intestine, lung, and mesenteric lymph nodes were ground with PBS. For RNA extraction, the cell supernatant was discarded, the $500 \mu \mathrm{L}$ Trizol was added. Then, total RNA was extracted and was reversed transcription as cDNA using a GoScript ${ }^{\mathrm{TM}}$ RT reagent Kit (Promega, Madison, WI, USA). Reverse transcription was performed at $42{ }^{\circ} \mathrm{C}$ for $15 \mathrm{~min}$, and $72{ }^{\circ} \mathrm{C}$ for $15 \mathrm{~min}$, in a reaction mix containing $2 \mu \mathrm{g}$ of isolate RNA, $1 \times$ Reverse Transcription Buffer, $2.5 \mathrm{mM} \mathrm{MgCl}_{2}, 1 \mathrm{mM}$ each dNTP, $1 \mathrm{U} / \mu \mathrm{L}$ Recombinant RNasin ${ }^{\circledR}$ Ribonuclease Inhibitor, $15 \mathrm{U} / \mu \mathrm{g}$ AMV Reverse Transcriptase and $0.5 \mu \mathrm{g}$ Oligo(dT) ${ }_{15}$ Primer or Random Primers in a final volume of $20 \mu \mathrm{L}$ [17].

To detect PPRV infection with GTC, cells were infected with PPRV ChinaSX2020 for 24 $\mathrm{h}, 48 \mathrm{~h}$ and $72 \mathrm{~h}$. Quantitative real-time PCR (qPCR) was performed using PPRV-H primers (forward: $5^{\prime}$-CTGAATACCAACATTGAG-3', reverse: $5^{\prime}$-GAGGAACTTAATCTTATCG-3'), and goat $\beta$-actin primers (forward: $5^{\prime}$-ACCAAACAAAGTTGGGTAAGG-3', reverse: $5^{\prime}$ AGTCCACATCGCTGTCGTCAGATC- $3^{\prime}$ ) Then, detections were carried out in the Mx3005p system (Agilent Technologies, Palo Alto, CA, USA) following the manufacturer's instructions. Data analysis was performed using the $2^{-\Delta \Delta C T}$ relative quantification method. For PPRV detection by PCR, N gene (351 bp) was used, and the primers were from reference [18]. 
For PCR amplification, 11 pairs of primers were designed to target the reference sequences of PPRV. The full-genome sequence of PPRV was spliced by a nested PCR assay. The amplified products were separated on a $1.0 \%$ agarose gel and purified with a DNA gel extraction kit. Then, the PCR products were sequenced using standard Sanger methods at TsingKe Biological Technology (Xi'an, China). The PCR primers designed to amplify the 11 overlapping fragments are listed in Table 1.

Table 1. Primers used in this study.

\begin{tabular}{|c|c|c|}
\hline Gene ID & Forward Primer $\left(5^{\prime}-3^{\prime}\right)$ & Reverse Primer $\left(5^{\prime}-3^{\prime}\right)$ \\
\hline P1 & ACCAAACAAAGTTGGGTAAGG & ACCAAACAAAGTTGGGTAAGG \\
\hline $\mathrm{P} 2$ & GATTGAAGGACTCGAGGATGCTGAC & TGATGATGACATCATCGTAGACACGG \\
\hline P3 & ACCCTAGAAGATACATAGTCGGCTCATG & TCTCGTATGGACTTGGCCCCTAA \\
\hline $\mathrm{P} 4$ & GGACGCAGAAAGGAAGGAGACAC & CССССТGAAACATTCCTGAAGCA \\
\hline P5 & GCCAAGCCACCAGACTCTGGTTATA & CATGTCTGTGTGTGATGCCAGATGA \\
\hline P6 & GCACCAATTTAGGCAATGCAGTCAC & CCCGAGAGTCAAAGATTGCAGCTTT \\
\hline P7 & TACAAGGCTGCGGTCAAGTCAATTG & ATATCTCTGGTCTATGGCCATGGCT \\
\hline P8 & TCGCGAGACCTCGTTGTGATAATTG & GCCGCTCTGGTTTCATCCACTATAG \\
\hline P9 & GCTGCACTGAAGAATGAGTGGGATTC & AGAGGTTCTCAAGGATCCCAAGACC \\
\hline P10 & GACAATCAGACAATCGCAGTGACGA & TGGATGTGGAGACTGGAGTGATCAT \\
\hline P11 & GACATCCCTTGTGAGGGTTGCAAGATAC & ACCAGACAAAGCTGGGAATAGATAC \\
\hline
\end{tabular}

\subsection{Serology for Detection of Antibodies Directed against PPR Virus}

For the last three years, our laboratory has been monitoring PPRV infection and has collected a large number of sheep serum. Then, samples of sheep were collected for preliminary PPR serological analysis in the Lanzhou Veterinary Research Institute, Chinese Academy of Agricultural Sciences (LVRI-CAAS, Lanzhou, China). Serological tests were performed using blocking ELISA (bELISA) based on the PPRV N protein purchased from Qingdao ReGen diagnostics development center.

\subsection{Phylogenetic Analysis}

The genome sequences of PPRV obtained in this study have been deposited in GenBank. The phylogenetic relationship of PPRV strains was analysed using MEGA6.0. Additionally, the phylogenetic tree was further constructed using the neighbour-joining method by bootstrap analysis with 1000 repetitions.

\section{Results}

\subsection{Serological Analysis}

To investigate the prevalence of PPRV in China, a retrospective serological study was performed on the sera samples collected from some provinces in China during 2018-2020. We found that 75 out of a total of $573(13.09 \%)$ were positive, while $413(72.07 \%)$ were negative and 85 (14.83\%) were inconclusive when tested using the N-based PPR-bELISA according to the instructions (Table 2). These results revealed that PPRV might be epidemic in some areas of China. 
Table 2. Retroactive serological survey for the detection of anti-PPRV antibodies in sera collected in China.

\begin{tabular}{|c|c|c|c|c|c|c|}
\hline & \multirow[b]{2}{*}{ Time of Sample } & & \multirow[b]{2}{*}{ No. of Samples } & \multicolumn{3}{|c|}{ NPPR-bELISA Test Results } \\
\hline & & & & Positive & Negative & Inconclusive \\
\hline County & Collection & Sample Type & Analysed & $\mathrm{PI} \geq 60 \%$ & $\mathrm{PI} \leq 40 \%$ & PI: $40-60 \%$ \\
\hline Inner Mongolia & Mar. 2018 & Serum & 80 & 14 & 56 & 10 \\
\hline Jinchang & May. 2018 & Serum & 192 & 15 & 142 & 35 \\
\hline Zhang Jiachuan & Oct. 2018 & Serum & 10 & 2 & 8 & 0 \\
\hline Longnan & Jun. 2019 & Serum & 90 & 12 & 62 & 16 \\
\hline Jinchang & Aug. 2019 & Serum & 145 & 25 & 98 & 22 \\
\hline Shaanxi & Jul. 2020 & Serum & 56 & 7 & 47 & 2 \\
\hline Total & & & 573 & $75 / 573(13.09 \%)$ & $413 / 573(72.07 \%)$ & $85 / 563(14.83 \%)$ \\
\hline
\end{tabular}

The N-based PPR-bELISA test results are interpreted as follows: PI values below or equal to $40 \%$ (PI $\leq 40)$ are negative, PI values greater than $60 \%(P I \geq 60)$ are positive, and PI values greater than $40 \%$ and below $60 \%$ are doubtful.

\subsection{PPRV Identification}

To further understand the epidemiological surveillance of PPRV, in July 2020, clinical samples were collected from dead domestic milk goats, which were suspected to have died of PPRV in a sheep yard of Xi'an country Shannxi province. Prior to their death, they displayed symptoms of PPR infection, such as cough, dyspnoea, mucopurulent ocular, nasal discharge and diarrhoea [19]. A complete necropsy was performed, and tissue samples including lung, spleen, small intestine and mesenteric lymph nodes were sent to the laboratory on ice for further detection. These tissues were ground with cold PBS. Then, they were centrifuged at $4{ }^{\circ} \mathrm{C}, 8000 \mathrm{rpm}$ for $30 \mathrm{~min}$ and were stored at $-80{ }^{\circ} \mathrm{C}$ for further investigation. qPCR analysis investigated that the spleen, small intestine, lung, and mesenteric lymph nodes were positive for PPRV (Figure 1A). Moreover, PCR results showed that the $\mathrm{N}$ gene amplification size was $351 \mathrm{bp}$ (Figure 1B). Taken together, these data suggested that the domestic milk goats were infected with PPRV.

A

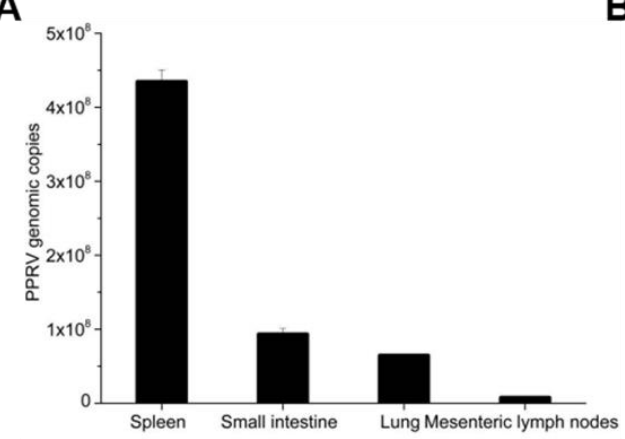

B

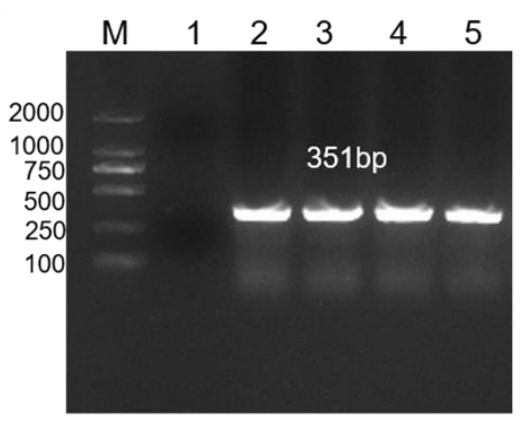

Figure 1. Identification of the PPRV. (A) PPRV infection was detected by qPCR. Genomic copies of PPRV per gram of tissues; (B) PPRV infection was detected by PCR with N fragment. M: DL2000. (1) Negative control; (2) lung; (3) spleen; (4) small intestine; (5) mesenteric lymph nodes.

Afterwards, the ground and homogenized spleen was used for virus infection. The results showed that GTC produced more cytopathic effect (CPE) at $48 \mathrm{~h}$ and $72 \mathrm{~h}$ during PPRV infection (Figure 2A). Additionally, an indirect immunofluorescence assay (IFA) indicated that the expression of PPRV-N protein was obviously observed during PPRV infection (Figure 2B). And the mRNA level (Figure 2C) and virus titer (Figure 2D) of PPRV increased significantly after infection, indicating that PPRV was replicated in GTC cells. 

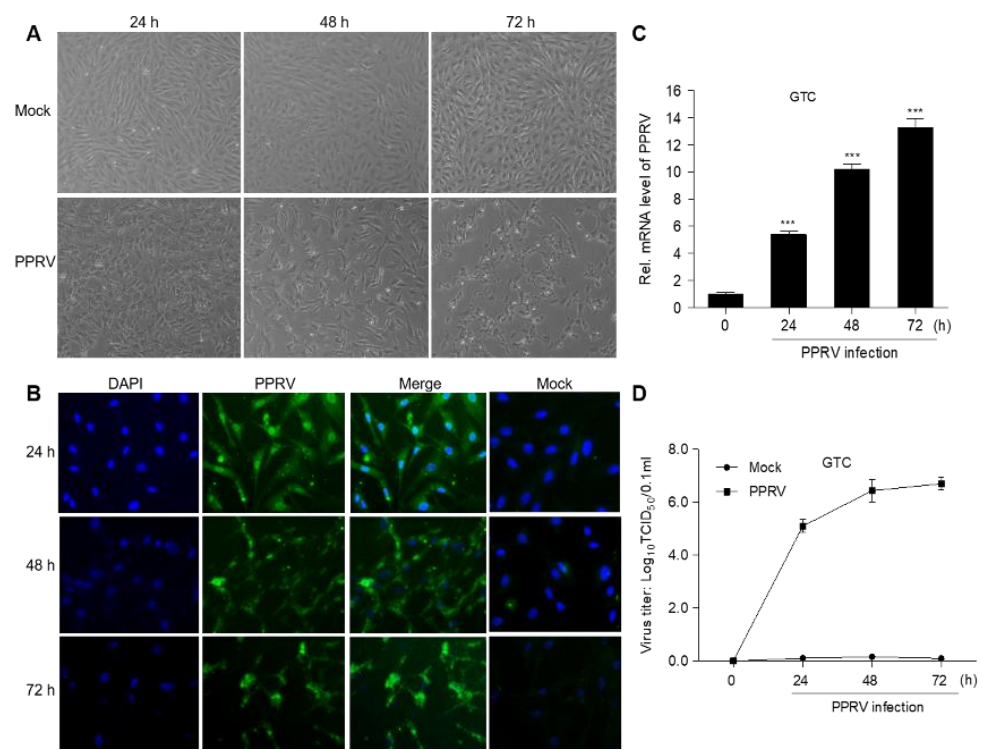

Figure 2. PPRV infected with GTC. (A) CPE was observed by microscope; (B) indirect immunofluorescence of GTC infected with PPRV; (C) PPRV replication was detected by qPCR; (D) virus titer of PPRV was determined by qPCR. The data represent the mean $\pm \mathrm{SD}$ of three independent experiments. One-way ANOVA; ${ }^{* * *} p<0.001$.

\subsection{PPRV Identification and Sequencing}

Additionally, the virus was concentrated and purified. Transmission electron microscopy revealed spherical, enveloped virus particles, with a mean diameter of $250 \mathrm{~nm}$ (range-200-400 nm) (Figure 3A), which was consistent with those of the reported PPRV particles. This PPRV strain was named ChinaSX2020. 11 fragments were amplified by PCR using ChinaSX2020 cDNA (Figure 3B), whereafter the amplifications of 11 segments were sequenced and spliced to obtain the complete genome sequence of ChinaSX2020.

\section{A}

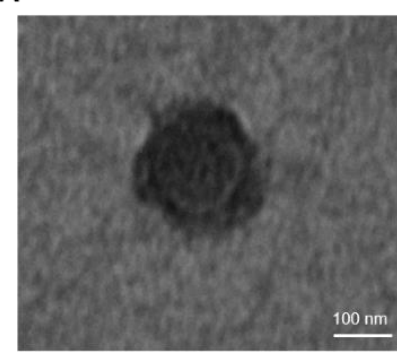

B

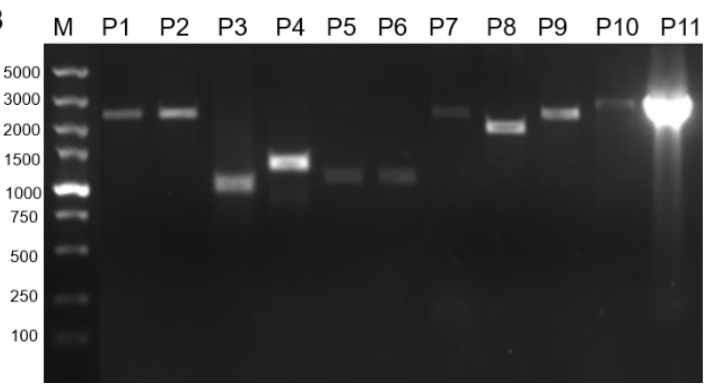

Figure 3. Electron microscopy image of virus particles and amplification of the full-length genome of PPRV. (A) Electron microscopy image of PPRV particles; (B) the full-length genome of PPRV was amplified by 11 fragments.

\subsection{Multiple Alignment and Phylogenetic Analysis}

The complete genome sequence obtained from this study has been submitted to GenBank and the accession number was MW344288. Afterwards, the phylogenetic analysis tree of PPRV was constructed. We found that the ChinaSX2020 strain belonged to the lineage IV genotype, which is the same as the ChinaGS2018 isolated in our laboratory in 2018. These two sequences showed good conformity with the PPRV complete genome sequences in China available on GenBank (Figure 4). The genome of ChinaSX2020 is 15,954 nucleotides long, with a GC content of $48.18 \%$. Compared with the full genomes of other PPRV strains, it was found that the genome of ChinaSX2020 showed the highest nucleotide sequence identity to PPRV isolated in China between 2013 and 2014. 


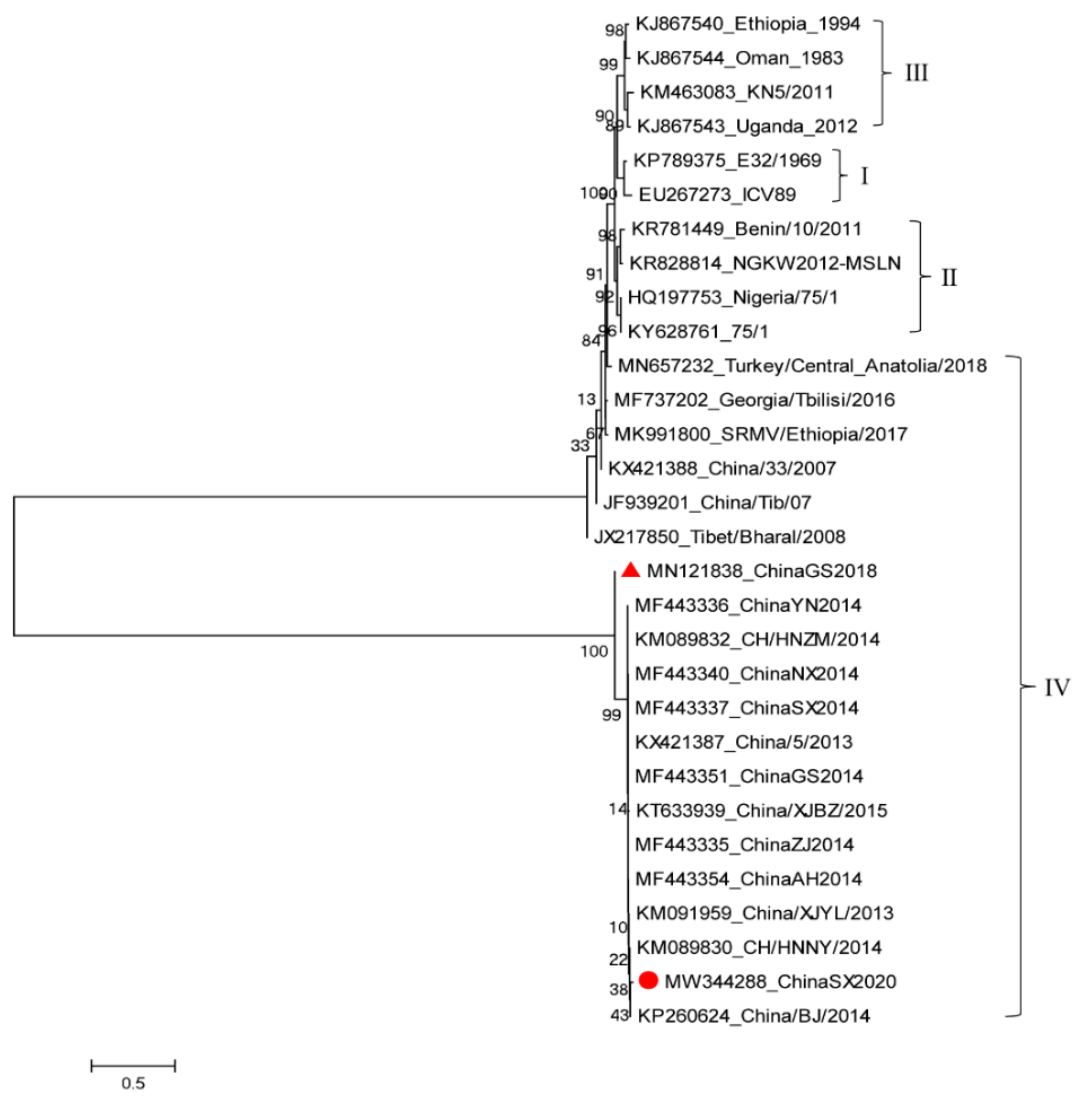

Figure 4. The phylogenetic tree analysis of PPRV. The ChinaSX2020 sequenced in this study is marked as a red dot in the tree. The ChinaGS2018 sequenced in our previous study is marked as a red triangle in the tree.

\section{Discussion}

Outbreaks of PPRV in free-ranging, wild artiodactyls can not only decimate them, but even threaten wildlife populations and ecosystems [20]. Over recent years, PPRV has been spreading across Asia and Africa [21]. There are more than 70 million sheep and goats, according to the official data published by the OIE in China. Additionally, the incidence rate of PPRV in Asia and Africa is high [22], which will have a major impact on the region's breeding industry. Due to the potential effects of the viral synonymous codon usage bias exhibited by an RNA virus, PPRV is continuously evolving [23]. In July 2007, the lineage IV PPRV was firstly descripted according to the reported PPR outbreaks that have occurred regularly from November 2013 until now in different regions of China [24]. Lineage IV was also found across the Middle East, Southern Asia and several African territories [25]. Additionally, with the increasing population densities of goats, the probability of PPRV occurrence was still high, which also threatens food security. Therefore, achieving global PPRV eradication appears to be particularly important [26].

In this study, the positive sera from these surveyed samples may be a result of antiPPRV antibodies' presence, the spread of PPRV in Asia, weak PPRV immunization measures, the existence of hot and humid climate conditions or other human factors [22]. Afterwards, the ChinaSX2020 was spliced by eleven fragments, and missing short sequences were usually amplified with a new set of primers. Polymerase chain reaction (RACE PCR) was used to rapidly amplify the cDNA ends to obtain the genome extremities [27]. ChinaSX2020 had the same length as most of the other PPRV genomes sequenced in China. ChinaSX2020 did not show sequence diversity like ChinaGS2018, but they had high homology, which suggested an ongoing circulation of PPRV in China. These findings showed that the recent PRRV is very similar to that isolated during the PRR outbreak in China between 2013 and 2014. These findings revealed that not the variety of PRRVs but 
the similar PPRVs were continuously spreading and causing sporadic outbreaks in China. In the absence of further information, it may originate from the PPR outbreaks in China during 2013-2014.

Over the last several years, PPR outbreaks have had a devastating effect on the economy over the last several years in China. Our previous study speculated that transboundary transmission may be an additional factor influencing the high prevalence of PPRV mortality among goats and sheep [6]. Although the majority of small ruminants are specific hosts to PPRV, domesticated cattle and buffalo are described as dead-end hosts [28]. Livestock production is associated with PPRV, such as the free movement of small ruminants, which could lead to the spread of PPRV. At present, efficacious vaccines are available against PPRV, such as Nigeria75/1 and Sungri96/1, but poor disease surveillance, low vaccine coverage and uncontrolled animal movements, exacerbated the spread of PPRV across the world [29]. There is a high risk of importing small ruminants from abroad, especially from countries with large populations of sheep and goats, which are likely to carry PPRV [30]. Additionally, vigorous monitoring is valuable for controlling and eradicating PPR [31].

To sum up, this study reported a new strain of PPRV named ChinaSX2020, which was from a domestic milk goat from Shannxi province in China. This strain was sequenced and identified as belonging to lineage PPRV IV. Additionally, the genome of ChinaSX2020 showed a 99\% nucleotide sequence identical with other PPRV in China between 2013 and 2014. This report will provide new information regarding the prevention and epidemiological surveillance of PPRV to eradicate the PPR disease globally.

Author Contributions: Conceptualization, J.W. and L.L.; formal analysis, J.W.; resources, X.C.; writing-original draft preparation, L.L.; writing—review and editing, L.L.; supervision, J.H.; project administration, X.L.; funding acquisition, Y.S. All authors have read and agreed to the published version of the manuscript.

Funding: This study was supported by Key R \& D plan project of Ningxia Autonomous Region in 2021 (2021BEF0206) and China Agriculture Research System of MOF and MARA (CARS-39-04B).

Institutional Review Board Statement: Not applicable.

Informed Consent Statement: Not applicable.

Conflicts of Interest: The authors declare no competing financial interests or conflicts.

\section{References}

1. Characterization of a seal morbillivirus. Nature 1988, 336, 115-116. [CrossRef]

2. Kumar, N.; Maherchandani, S.; Kashyap, S.K.; Singh, S.V.; Sharma, S.; Chaubey, K.K.; Ly, H. Peste Des Petits Ruminants Virus Infection of Small Ruminants: A Comprehensive Review. Viruses 2014, 6, 2287-2327. [CrossRef]

3. Banyard, A.C.; Parida, S.; Batten, C.; Oura, C.; Kwiatek, O.; Libeau, G. Global distribution of peste des petits ruminants virus and prospects for improved diagnosis and control. J. Gen. Virol. 2010, 91, 2885-2897. [CrossRef]

4. Dou, Y.; Liang, Z.; Prajapati, M.; Zhang, R.; Li, Y.; Zhang, Z. Expanding Diversity of Susceptible Hosts in Peste Des Petits Ruminants Virus Infection and Its Potential Mechanism Beyond. Front. Vet.-Sci. 2020, 7, 66. [CrossRef]

5. Shaila, M.S.; Shamaki, D.; Forsyth, M.A.; Diallo, A.; Goatley, L.; Kitching, R.P.; Barrett, T. Geographic distribution and epidemiology of peste des petits ruminants virus. Virus Res. 1996, 43, 149-153. [CrossRef]

6. Li, L.; Cao, X.; Wu, J.; Dou, Y.; Meng, X.; Liu, D.; Liu, Y.; Shang, Y.; Liu, X. Epidemic and evolutionary characteristics of peste des petits ruminants virus infecting Procapra przewalskii in Western China. Infect. Genet. Evol. 2019, 75, 104004. [CrossRef]

7. Parida, S.; Muniraju, M.; Altan, E.; Baazizi, R.; Raj, G.D.; Mahapatra, M. Emergence of PPR and its threat to Europe. Small Rumin. Res. 2016, 142, 16-21. [CrossRef] [PubMed]

8. Pruvot, M.; Fine, A.E.; Hollinger, C.; Strindberg, S.; Damdinjav, B.; Buuveibaatar, B.; Chimeddorj, B.; Bayandonoi, G.; Khishgee, B.; Sandag, B.; et al. Outbreak of Peste des Petits Ruminants among Critically Endangered Mongolian Saiga and Other Wild Ungulates, Mongolia, 2016-2017. Emerg. Infect. Dis. 2020, 26, 51-62. [CrossRef]

9. Prajapati, M.; Alfred, N.; Dou, Y.; Yin, X.; Prajapati, R.; Li, Y.; Zhang, Z. Host Cellular Receptors for the Peste des Petits Ruminant Virus. Viruses 2019, 11, 729. [CrossRef] [PubMed]

10. Liu, F.; Li, J.; Li, L.; Liu, Y.; Wu, X.; Wang, Z. Peste des petits ruminants in China since its first outbreak in 2007: A 10-year review. Transbound Emerg. Dis. 2018, 65, 638-648. [CrossRef] [PubMed]

11. Bao, J.; Wang, Q.; Li, L.; Liu, C.; Zhang, Z.; Li, J.; Wang, S.; Wu, X.; Wang, Z. Evolutionary dynamics of recent peste des petits ruminants virus epidemic in China during 2013-2014. Virology 2017, 510, 156-164. [CrossRef] 
12. Gao, S.; Xu, G.; Zeng, Z.; Lv, J.; Huang, L.; Wang, H.; Wang, X. Transboundary spread of peste des petits ruminants virus in western China: A prediction model. PLoS ONE 2021, 16, e0257898. [CrossRef]

13. Rojas, J.M.; Sevilla, N.; Martín, V. A New Look at Vaccine Strategies Against PPRV Focused on Adenoviral Candidates. Front. Vet.-Sci. 2021, 8, 1005. [CrossRef]

14. Kamel, M.; El-Sayed, A. Toward peste des petits virus (PPRV) eradication: Diagnostic approaches, novel vaccines, and control strategies. Virus Res. 2019, 274, 197774. [CrossRef] [PubMed]

15. Njeumi, F.; Bailey, D.; Soula, J.J.; Diop, B.; Tekola, B.G. Eradicating the Scourge of Peste Des Petits Ruminants from the World. Viruses 2020, 12, 313. [CrossRef] [PubMed]

16. Balamurugan, V.; Hemadri, D.; Gajendragad, M.R.; Singh, R.K.; Rahman, H. Diagnosis and control of peste des petits rumi-nants: A comprehensive review. Virusdisease 2014, 25, 39-56. [CrossRef] [PubMed]

17. Han, S.; Hu, W.; Kan, W.; Ge, Z.; Song, X.; Li, L.; Shang, Y.; Zeng, Q.; Zhou, J.-H. Analyses of genetics and pathogenesis of Salmonella enterica $\mathrm{QH}$ with narrow spectrum of antibiotic resistance isolated from yak. Infect. Genet. Evol. 2020, 82, 104293. [CrossRef]

18. Manjunath, S.; Saxena, S.; Mishra, B.; Santra, L.; Sahu, A.R.; Wani, S.A. Early transcriptome profile of goat peripheral blood mononuclear cells (PBMCs) infected with peste des petits ruminant's vaccine virus (Sungri/96) revealed induction of antiviral response in an interferon independent manner. Res. Vet. Sci. 2019, 124, 166-177. [CrossRef]

19. Kinimi, E.; Mahapatra, M.; Kgotlele, T.; Makange, M.R.; Tennakoon, C.; Njeumi, F.; Odongo, S.; Muyldermans, S.; Kock, R.; Parida S.; et al. Complete Genome Sequencing of Field Isolates of Peste des Petits Ruminants Virus from Tanzania Revealed a High Nucleotide Identity with Lineage III PPR Viruses. Animals 2021, 11, 2976. [CrossRef]

20. Aguilar, X.F.; Fine, A.E.; Pruvot, M.; Njeumi, F.; Walzer, C.; Kock, R.; Shiilegdamba, E. PPR virus threatens wildlife conservation. Science 2018, 362, 165-166. [CrossRef]

21. Hemida, M.G.; Alghadeer, H.M.; Alhammadi, M.; Ali, S. Prevalence and molecular characterization of some circulating strains of the peste-des-petits-ruminants virus in Saudi Arabia between 2014-2016. PeerJ 2020, 8, e9035. [CrossRef]

22. Ahaduzzaman, M. Peste des petits ruminants (PPR) in Africa and Asia: A systematic review and meta-analysis of the prev-alence in sheep and goats between 1969 and 2018. Vet. Med. Sci. 2020, 6, 813-833. [CrossRef] [PubMed]

23. Ma, X.X.; Wangm, Y.N.; Cao, X.A.; Li, X.R.; Liu, Y.S.; Zhou, J.H. The effects of codon usage on the formation of secondary structures of nucleocapsid protein of peste des petits ruminants virus. Genes Genom. 2018, 40, 905-912. [CrossRef]

24. Ma, J.; Gao, X.; Liu, B.; Chen, H.; Xiao, J.; Wang, H. Peste des petits ruminants in China: Spatial risk analysis. Transbound. Emerg. Dis. 2019, 66, 1784-1788. [CrossRef] [PubMed]

25. Dundon, W.G.; Diallo, A.; Cattoli, G. Peste des petits ruminants in Africa: A review of currently available molecular epidemiological data, 2020. Arch Virol. 2020, 165, 2147-2163. [CrossRef]

26. Albina, E.; Kwiatek, O.; Minet, C.; Lancelot, R.; de Almeida, R.S.; Libeau, G. Peste des petits ruminants, the next eradicated animal disease? Vet.-Microbiol. 2013, 165, 38-44. [CrossRef] [PubMed]

27. Eloiflin, R.J.; Boyer, M.; Kwiatek, O.; Guendouz, S.; Loire, E.; de Almeida, R.S. Evolution of Attenuation and Risk of Reversal in Peste des Petits Ruminants Vaccine Strain Nigeria 75/1. Viruses 2019, 11, 724. [CrossRef]

28. Rahman, A.-U.; Dhama, K.; Ali, Q.; Hussain, I.; Oneeb, M.; Chaudhary, U.N.; Wensman, J.J.; Shabbir, M.Z. Peste des petits ruminants in large ruminants, camels and unusual hosts. Vet.-Q. 2020, 40, 35-42. [CrossRef] [PubMed]

29. Idoga, E.S.; Armson, B.; Alafiatayo, R.; Ogwuche, A.; Mijten, E.; Ekiri, A.B.; Varga, G.; Cook, A.J.C. A Review of the Current Status of Peste des Petits Ruminants Epidemiology in Small Ruminants in Tanzania. Front. Vet.-Sci. 2020, 7. [CrossRef]

30. Banyard, A.C.; Wang, Z.; Parida, S. Peste des Petits Ruminants Virus, Eastern Asia. Emerg. Infect. Dis. 2014, $20,2176-2178$. [CrossRef]

31. Jones, B.; Mahapatra, M.; Mdetele, D.; Keyyu, J.; Gakuya, F.; Eblate, E.; Lekolool, I.; Limo, C.; Ndiwa, J.; Hongo, P.; et al. Peste des Petits Ruminants Virus Infection at the Wildlife-Livestock Interface in the Greater Serengeti Ecosystem, 2015-2019. Viruses 2021, 13, 838. [CrossRef] [PubMed] 